\title{
Pengaruh Pemberian Minuman Mix Juice terhadap Kadar Glukosa Darah dan Kebugaran Ibu Bersalin
}

\author{
Riana Pascawati ${ }^{1}$, Nurhalim Shahib ${ }^{2}$, Farid Husin ${ }^{3}$ \\ ${ }^{1}$ Jurusan Kebidanan, Polteknik Kesehatan Bandung, Indonesia \\ ${ }^{2}$ Departemen Biokimia dan Biologi Molekuler, Universitas Padjajaran Bandung, Indonesia \\ ${ }^{3}$ Departemen Ilmu Kesehatan Masyarakat, Universitas Padjadjaran Bandung, Indonesia \\ Email: rianapascawati@gmail.com
}

\begin{abstract}
Impact of Giving Mix Juice Drinks on Blood Glucose Levels and Maternity Fitness. Mix Juice is a mixture of fruits, nuts, and honey so it contains a lot of glucose and fructose. Glucose in the body functions as the main energy source to maintain fitness. This mix of juice drink can be consumed by the mother and quickly produces energy so that it can be an alternative to meet the nutritional needs of the mother during labor. This research was to analyze the effect of mixed juice drink on blood glucose levels and maternity fitness. This study was a Quasi-Experiment design with Randomized Control Trial. This randomized controlled trial study has used a sample of 60 parturient at Bandung City Community Health Centers which divided into two groups: intervention and control. Blood glucose level measured with a glucometer. Fitness was calculated from the pulse recovery using a pulse oximeter. Analysis using a TIndependent test. The results of the study showed significant differences in maternal blood glucose levels after drinking of mix juice, in the intervention group $(34,7)$ and control group $(16,4)$ with a value $(\mathrm{p}<0,05)$. There was fitness enhancement in the intervention group $(0,32)$ contrast with a control group who had decreased $(-2,21)$ with a value $(\mathrm{p} 0,05)$. The consumption of mix juice for parturient improve parturient's glucose level and fitness.
\end{abstract}

Keywords: Blood glucose levels, Maternity fitness, Mix juice drink, Nutrition during labor

\begin{abstract}
Abstrak: Pengaruh Pemberian Minuman Mix Juice terhadap Kadar Glukosa Darah dan Kebugaran Ibu Bersalin. Salah satu upaya agar kebutuhan cairan dan makanan tetap mencukupi serta memenuhi energi selama persalinan antara lain berupa pemberian minuman Mix Juice. Mix Juice merupakan campuran dari buah-buahan, kacang-kacangan dan madu sehingga relatif banyak mengandung glukosa dan fruktosa. Glukosa dalam tubuh berfungsi sebagai sumber energi utama untuk mempertahankan kebugaran. Minuman mix juice ini dapat dikonsumsi ibu dan cepat menghasilkan energi sehingga dapat menjadi alternatif pemenuhan kebutuhan nutrisi ibu selama proses persalinan. Tujuan penelitian ini menganalisis pengaruh pemberian minuman mix juice terhadap kadar glukosa darah dan kebugaran pada ibu bersalin. Penelitian ini menggunakan desain Quasi Eksperimen dengan pendekatan Randomised Controlled Trial. Sampel dalam penelitian ini adalah 60 responden di Puskesmas PONED Kota Bandung yang dikelompokkan menjadi kelompok intervensi dan kontrol. Kadar gukosa darah sewaktu diukur dengan glucometer. Kebugaran dihitung dari denyut nadi pemulihan menggunakan pulse oxymeter. Uji hipotesis untuk mengetahui pengaruh kedua variabel menggunakan uji T-Independent. Hasil penelitian terdapat perbedaan yang bermakna kadar glukosa darah ibu bersalin setelah pemberian minuman mix juice pada kelompok perlakuan $(34,7)$ dan kontrol $(16,4)$ dengan nilai $(\mathrm{p}<0,05)$. Peningkatan kebugaran pada kelompok perlakuan $(0,32)$ sedangkan pada kelompok kontrol mengalami penurunan $(-2,21)$ dengan nilai $(p<0,05)$. Pemberian minuman mix juice pada ibu bersalin selama persalinan berpengaruh terhadap peningkatan kadar glukosa darah dan kebugaran ibu bersalin.
\end{abstract}

Kata kunci: Kadar glukosa darah, Kebugaran ibu bersalin, Minuman mix juice, Nutrisi persalinan

\section{PENDAHULUAN}

Persalinan merupakan suatu proses fisiologis yang membutuhkan energi dan stamina. Saat persalinan ibu bersalin masih menginginkan makanan pada kala I fase laten. Memasuki kala I fase aktif ibu bersalin enggan untuk mengkonsumsi makanan dikarenakan rasa nyeri yang semakin sering sehingga keinginan untuk makan dan minum berkurang. Hal ini sesuai dengan hasil studi pendahuluan di Klinik Padjajaran Jatinangor terhadap $30 \mathrm{ibu}$ bersalin mengenai pola pemenuhan nutrisi dan hidrasi mereka selama proses persalinan, memperoleh hasil pada persalinan kala I fase laten masih berkeinginan mengkonsumsi makanan dan 
minuman sebanyak $87 \%$. Ibu yang menginginkan makanan pada persalinan kala I fase aktif sebanyak $40 \%$, sedangkan pada kala II persalinan sebanyak 6\%. Rata-rata konsumsi kalori ibu sebesar $30 \mathrm{kkal}$ per jam. Proses persalinan terutama pada kala I fase aktif dan kala II memerlukan banyak energi sehingga kebutuhan nutrisi perlu mendapat perhatian yang khusus dari pengelola persalinan sehingga meminimalkan terjadinya kelelahan. (Mello, 2007)

Intensitas aktivitas fisik selama persalinan relatif sama dengan moderate continous exercise pada atlet olahraga oleh karena pola gerak ibu selama persalinan tergolong intensitas sedang dan berat. Selama persalinan di rekomendasi asupan cairan dan makanan dikarenakan proses persalinan yang dapat berlangsung lama akan membutuhkan konsumsi energi yang besar sehingga dibutuhkan pula nutrisi yang adekuat (Maharaj D, 2009).

Asupan nutrisi diutamakan untuk pemenuhan energi yang dibutuhkan untuk optimalisasi fungsi organ-organ yang berperan dalam persalinan, antara lain: fungsi jantung paru dan pembuluh darah, fungsi otot dasar panggul dan fungsi otot uterus. Ibu bersalin masih menginginkan makanan pada kala I fase laten. Memasuki kala I fase aktif ibu bersalin enggan untuk mengkonsumsi makanan dikarenakan rasa nyeri yang semakin sering sehingga keinginan untuk makan dan minum berkurang.

Pemenuhan nutrisi dan hidrasi merupakan faktor penting selama proses persalinan untuk menjamin kecukupan energi dan keseimbangan cairan dan elektrolit normal pada ibu. Asuhan persalinan normal dianjurkan pemberian asupan nutrisi pada ibu bersalin, namun selama ini kebutuhan nutrisi ibu tidak terlalu diperhitungkan sehingga kita tidak mengetahui apakah kebutuhan nutrisi ibu telah tercukupi atau belum (Rahmani $\mathrm{R}$ et al, 2012). Beberapa penelitian menjelaskan bahwa tambahan kebutuhan energi ibu bersalin diestimasika sebesar 50-100 kkal/jam (ACNM, 2008; Melo, 2007; Malin, 2016).

Pada proses persalinan kala I fase aktif dan kala II menunjukkan aktivitas fisik yang relatif tinggi, hal ini membutuhkan sumber energi yang cukup. Aktifitas fisik pada masa persalinan membutuhkan energi melalui metabolism anaerob. Sumber utama energi pada aktifitas fisik yang relatif tinggi dengan metabolism anaerob berasal dari glukosa dan fruktosa. Sampai saat ini belum diketahui dengan jelas asupan makanan dan cairan yang tepat untuk mempertahankan fungsi organ-organ yang berkaitan dengan persalinan tetap optimal. Oleh karena itu disarankan peningkatan penyerapan glukosa dari luar selain mengandalkan cadangan dari dalam tubuh (Benfield RD et al, 2014).

Asupan kalori yang cukup selama persalinan akan mempertahankan kadar glukosa darah ibu bersalin, sehingga kebugaran ibu selama menjalani proses persalinan juga terjaga. Salah satu upaya agar kebutuhan cairan dan makanan tetap mencukupi serta memenuhi energi selama persalinan antara lain pemberian minuman Mix Juice.

Minuman Mix Juice merupakan campuran dari buah-buahan, kacang-kacangan, dan madu yang relatif banyak mengandung glukosa dan fruktosa yang diperlukan oleh tubuh untuk energi. Mix Juice ini tidak menyebabkan efek samping karena menggunakan bahan-bahan alami. Selain itu memiliki nilai nutrisi yang baik yang cepat didistribusikan ke dalam darah dan dapat dimanfaatkan untuk kebutuhan energi oleh tubuh manusia. Selain itu cepat menghasilkan energi karena kandungan gula alami yang mampu mempertahankan konsentrasi gula darah. Inovasi pembuatan Mix Juice ini diharapkan dapat memenuhi kebutuhan selama persalinan dan terutama pada kala II, sehingga pembuatannya dicampurkan dari beberapa jenis buah dan bahan yang dapat mencukupi kebutuhan energi ibu bersalin (Wauthoz N, 2007; PAGI, 2009; Mariyam, 2015; Herch W et al, 2014; Bogdanov S et al, 2008; Etebu E et al, 2014).

Alternatif tambahan nutrisi ini bisa dikonsumsi ibu dan cepat menghasilkan energi sehingga kebutuhan nutrisi terpenuhi dan tingkat kebugaran ibu selama persalinan tetap terjaga.

\section{METODE}

Penelitian ini menggunakan desain Quasi Experimental dengan pendekatan Randomized Controlled Trial Pre-Post Test With Control Group Design yang dilakukan pada 60 subjek yaitu ibu yang akan melahirkan di Puskesmas PONED di Kota Bandung. Sampel dalam penelitian ini sebesar 20 subjek penelitian yang dihitung dengan rumus numerik sampel dua ratarata data tidak berpasangan. Pengambilan sampel dilakukan berdasarkan consecutive sampling. Upaya mengantisipasi apabila ada data yang tidak bisa digunakan, klien drop out atau tidak taat protokol maka dilakukan penambahan subjek sebesar 50\% dari total subjek agar besar sampel tetap terpenuhi. Jumlah kemungkinan drop out sebesar 10 subjek penelitian, maka jumlah sampel yang diperlukan pada tiap kelompok dalam penelitian ini adalah 30 subjek. Kriteria 
inklusi yang digunakan yaitu ibu usia 20-35 tahun, kehamilan kurang dari 4 yang datang pada fase laten persalinan (dengan pembukaan kurang dari $4 \mathrm{~cm}$ ), hasil pemeriksaan obstetrik bayi aterm, tunggal, dan sehat, IMT normal sebelum hamil $18,5-24,9 \mathrm{~kg} / \mathrm{m}^{2}$. Kriteria eksklusi yaitu mempunyai alergi kacang-kacangan dan penyakit gastritis, mengalami komplikasi pada masa kehamilan seperti diabetes melitus, hyperemesis gravidarum dan hipertensi, mengalami komplikasi saat persalinan seperti KPD dan eklamsia.

Penelitian dilaksanakan pada bulan Maret sampai dengan Mei 2017. Variabel bebas dalam penelitian ini adalah pemberian minuman mix juice dengan pemberian 300cc (mengandung 300 kkal) per botol setiap 3 jam. Variabel terikat dalam penelitian ini adalah kadar glukosa darah dan kebugaran. Variabel perancu pada penelitian ini adalah durasi persalinan, gravida dan tingkat kecemasan.

Berdasarkan data di tempat penelitian, peneliti mendapatkan informasi mengenai calon subjek penelitian yang akan melahirkan di lima puskesmas yang menjadi tempat penelitian. Kemudian melakukan melakukan blok random untuk menentukan apakah subjek penelitian masuk kedalam kelompok perlakuan atau kelompok kontrol serta menjelaskan prosedur penelitian. Melakukan informed consent pada subjek penelitian yang memenuhi kriteria dan bersedia. Selanjutnya enumerator melakukan pengambilan sampel darah kapiler dan diukur kadar glukosa darah menggunakan glucometer merek accu-check kemudian dicatat hasilnya. Selanjutnya mengukur tingkat kebugaran menggunakan nadi pemulihan menggunakan pulse oximeter merek Bauer. Kemudian hasilnya dikonversikan kedalam rumus $\mathrm{VO}_{2} \max =65.81$ [0.1847×pulse rate beats $/ \mathrm{min}] \quad[\mathrm{ml} / \mathrm{kg} / \mathrm{min}]$ (Khushoo TN et al, 2015). Enumerator memberikan minuman mix juice pada subjek penelitian di kelompok perlakuan dan mencatat sisa minuman yang dikonsumsi. Pemberian minuman mix juice diberikan setiap 2 jam sekali selama fase persalinan dan dipantau setiap dua jam sekali. Enumerator bertugas untuk memantau jumlah minuman mix juice yang telah dihabiskan oleh ibu. Ibu pada kelompok kontrol dibebaskan untuk mengkonsumsi makanan dan minuman yang dicatat ke dalam formulir record. sehingga diketahui jumlah kalori yang dimakan. Pada tahap akhir penelitian, enumerator melakukan pemeriksaan ulang kadar glukosa darah segera setelah kelahiran plasenta pada kedua kelompok dan mencatat hasilnya. Selanjutnya mengukur tingkat kebugaran post 15 menit setelah ibu dibersihkan pada kala IV persalinan.

Bahan yang digunakan untuk membuat formulasi minuman mix juice adalah madu PT. Perhutani. Buah-buahan yaitu kurma dengan varietas tunisia kering, jambu biji merah, mangga indramayu, jeruk manis medan dan kacang merah kering rebus. yang telah dihitung komponennya sesuai dengan kebutuhan energi ibu bersalin. Proporsi disesuaikan dengan kebutuhan ibu bersalin dengan komposisi karbohidrat $70 \%$, protein $15 \%$ dan lemak $15 \%$ (DL T, 2008; Potgieter S, 2013).

Formula mix juice sudah melalui uji organoleptik yang dilakukan di laboratorium Teknologi Pangan Universitas Pasundan. Sebelum penilaian dilakukan formulasi untuk memperoleh komposisi formula minuman yang menghasilkan minuman yang terstandar. Formula minuman mix juice dibuat tiga formula yang berbeda dan masing-masing dilakukan uji organoleptik untuk memperoleh formula terbaik yang dapat diterima oleh responden dengan empat kriteria penilaian meliputi warna, aroma, rasa dan tekstur. Formula terbaik berdasarkan panelis selanjutnya menjadi formula terpilih sebagai dasar pembuatan mix juice.

Proses pembuatan minuman mix juice diawali dengan penentuan kebutuhan energi Ibu bersalin per jam sebesar $100 \mathrm{kkal} / \mathrm{jam}$ yang diperhitungkan dari kebutuhan energi diam sebesar $50 \mathrm{kkal} / \mathrm{jam}$, ditambah kebutuhan energi tambahan selama persalinan 50-100 kkal/jam. Formula minuman mix juice dibuat setiap kebutuhan tiga jam yaitu sebesar 300 kkal. Proses selanjutnya dilakukan dari persiapan bahan dari pemilihan/ penyortiran, pengupasan, pencucian, perendaman dan perebusan, pemotongan serta penimbangan beberapa macam buah. Selanjutnya dimasukkan kedalam slow juice dan terakhir pengemasan menggunakan botol kaca. Supaya lebih tahan lama dilakukan pasteurisasi panas dengan suhu $70^{\circ}$ selama 15 menit. Setelah itu disimpan di lemari pendingin dengan suhu 5$15^{\circ} \mathrm{C}$ (Julianti E, 2006; Adji IS, 2010).

Berdasarkan SNI minuman khusus ibu hamil salah satu syarat minuman diantaranya dilihat Angka Lempeng Total (ALT) dan cemaran E. coli apakah dalam batas ambang yang diperkenankan atau tidak. Sehingga dilakukan analisis ini untuk mengetahui cemaran bakteri pada minuman sehingga bisa diketahui daya simpan minuman (SNI, 1995; SNI 2005). Hasil ALT pada hari keempat masih dalam batas normal yang diperkenankan, selain itu cemaran E. coli pada minuman juga masih negatif sampai 
hari keempat sehingga menjadi pedoman dalam pembuatan minuman setiap empat hari sekali.

Penelitian ini telah memperoleh ethical clearance dari Komisi Etik Penelitian Kesehatan (KEPK) Fakultas Kedokteran Universitas Padjadjaran Bandung No.264/UN6.C10/PN/2017. Analisis bivariat digunakan untuk mengetahui pengaruh masing-masing variabel. Data diuji normalitasnya dengan uji Saphiro-wilk. Seluruh data berdistribusi normal sehingga untuk mengetahui perbedaan kadar glukosa darah dan kebugaran sebelum dan sesudah perlakuan menggunakan uji $\mathrm{t}$ berpasangan. Perbedaan pengaruh kedua variabel menggunakan uji $T$ Independent.

\section{HASIL}

Tabel 1. Karakteristik Subjek Penelitian

\begin{tabular}{lrrr}
\hline \multirow{2}{*}{ Karakteristik } & \multicolumn{2}{c}{ Kelompok } & Nilai \\
\cline { 2 - 3 } $\boldsymbol{p}^{*}$
\end{tabular}

Berdasarkan tabel 1 pada dua kelompok penelitian tidak ada perbedaan yang bermakna $(p>0,05)$ antara kedua kelompok dalam hal usia, gravida, tingkat kecemasan, pekerjaan, indeks masa tubuh dan durasi persalinan. Hasil tersebut mengindikasikan homogenitas karakteristik subjek penelitian yang layak untuk diperbandingkan. Data pada kedua kelompok terdapat kesamaan dalam hal usia, gravida, tingkat kecemasan, pekerjaan, IMT dan durasi persalinan.

Tabel 2. Karakteristik Variabel Perancu

\begin{tabular}{lcrc}
\hline \multirow{2}{*}{ Karakteristik } & \multicolumn{2}{c}{ Kelompok } & \multirow{2}{*}{ Nilai $\boldsymbol{p}^{*}$} \\
\cline { 2 - 3 } & Perlakuan & \multicolumn{1}{c}{ Kontrol } & $0,407^{* *}$ \\
IMT & & & \\
x (SD) & $21,25(1,78)$ & $21,64(1,81)$ & \\
Rentang & $18,5-24,9$ & $18,61-24,9$ & \\
\hline Durasi Persalinan (menit) & & $0,066^{* *}$ \\
x (SD) & $271,5(81,9)$ & $321,5(121,0)$ & \\
Rentang & $125-473$ & $131-660$ & \\
\hline ** Uji T tidak berpasangan & &
\end{tabular}

Tabel 2 menggambarkan kedua variabel perancu tidak bermakna sehingga tidak berpengaruh pada kedua kelompok penelitian.

Tabel 3. Analisis Perbedaan Kadar Glukosa Darah Pre dan Post Pada Kelompok

\begin{tabular}{lcrll}
\hline $\begin{array}{c}\text { Kadar } \\
\text { Glukosa } \\
\text { Darah } \\
(\mathbf{m g} / \text { dl) }\end{array}$ & $\begin{array}{c}\text { Min - } \\
\text { Max }\end{array}$ & $\begin{array}{c}\text { Rerata } \pm \\
\text { SD }\end{array}$ & $\begin{array}{c}\text { Selisih } \\
\text { Rerata } \\
\text { Peningkatan } \\
\mathbf{\pm} \text { SD }\end{array}$ & p-value \\
\hline $\begin{array}{l}\text { Perlakuan } \\
\text { Pre }\end{array}$ & $70-103$ & $84,4 \pm 9,0$ & $34,7 \pm 8,9$ & $\left.<0,001^{*}\right)$ \\
Post & $102-130$ & $119,1 \pm 1,1$ & & \\
& & & & \\
Kontrol & & & $16,4 \pm 9,5$ & $\left.<0,001^{*}\right)$ \\
Pre & $70-104$ & $88 \pm 10,2$ & & \\
Post & $75-128$ & $104,4 \pm 16,4$ & & \\
& & & &
\end{tabular}

Peningkatan pre dan post kelompok perlakuan dan $\left.<0,001^{* *}\right)$ kontrol

Keterangan *) Uji T berpasangan **) Uji T tidak berpasangan

Tabel 3 menunjukkan bahwa terdapat perbedaan yang bermakna pada peningkatan kadar glukosa darah setelah pemberian minuman mix juice antara kelompok perlakuan dan kelompok kontrol $p<0,05$. Selain itu, pada kelompok perlakuan mengalami peningkatan kadar glukosa darah rata-rata lebih tinggi $(34,7)$ daripada kelompok kontrol $(16,4)$ dengan nilai $p<0,05$.

Tabel 4. Analisis Perbedaan Kebugaran Pre Dan Post Pada Kelompok Penelitian

\begin{tabular}{|c|c|c|c|}
\hline \multirow{2}{*}{$\begin{array}{l}\text { Kebugaran } \\
\text { (ml/kg/min) }\end{array}$} & \multicolumn{2}{|c|}{ Kelompok } & \multirow{2}{*}{ Nilai $p$} \\
\hline & Perlakuan & Kontrol & \\
\hline Pre & & & $0,714^{*}$ \\
\hline $\mathrm{x}(\mathrm{SD})$ & $49,6(1,4)$ & $49,5(1,7)$ & \\
\hline Median & 49,6 & 49,6 & \\
\hline Rentang & $47,5-53,2$ & $45,3-53,4$ & \\
\hline Kurang & $0(0 \%)$ & $1(3,3 \%)$ & \\
\hline Cukup & $11(36,7 \%)$ & $9(30 \%)$ & \\
\hline Baik & $19(63,3 \%)$ & $20(66,7 \%)$ & \\
\hline Post & & & $<0,001^{*}$ \\
\hline $\mathrm{X}(\mathrm{SD})$ & $50,0(1,2)$ & $47,3(1,4)$ & \\
\hline Median & 50,0 & 47,7 & \\
\hline Rentang & $47,7-52,6$ & $44,5-49,9$ & \\
\hline Kurang & $0(0 \%)$ & $5(17 \%)$ & \\
\hline Cukup & $6(20 \%)$ & $21(70 \%)$ & \\
\hline Baik & $24(80 \%)$ & $4(13 \%)$ & \\
\hline \multicolumn{4}{|l|}{$\begin{array}{l}\text { Peningkatan } \\
\text { pre dan post }\end{array}$} \\
\hline $\mathrm{x}(\mathrm{SD})$ & $0,32(1,5)$ & - & \\
\hline Persentase & 07 & $\begin{array}{r}2,21(1,71) \\
-438\end{array}$ & $<0001^{*}$ \\
\hline \multicolumn{4}{|c|}{ Keterangan *) Uji T tidak berpasangan } \\
\hline $\begin{array}{l}\text { Hasil a } \\
\mathrm{k} \text { terdapat } \\
\text { iberian mi } \\
\text { akuan dar } \\
\text { dapat per }\end{array}$ & $\begin{array}{l}\text { s kebug } \\
\text { daan yan } \\
\text { n mix jl } \\
\text { ntrol de } \\
\text { an yan }\end{array}$ & $\begin{array}{l}\text { an pada } \\
\text { bermakna } \\
\text { e antar } \mathrm{k} \\
\text { gan nilai } \\
\text { bermakn }\end{array}$ & $\begin{array}{r}\text { abel } 4 \\
\text { ebelum } \\
\text { lompok } \\
p>0,05 . \\
\text { pada }\end{array}$ \\
\hline
\end{tabular}


kebugaran setelah pemberian minuman mix juice antara kelompok perlakuan dan kelompok kontrol dengan nilai $p<0,05$.

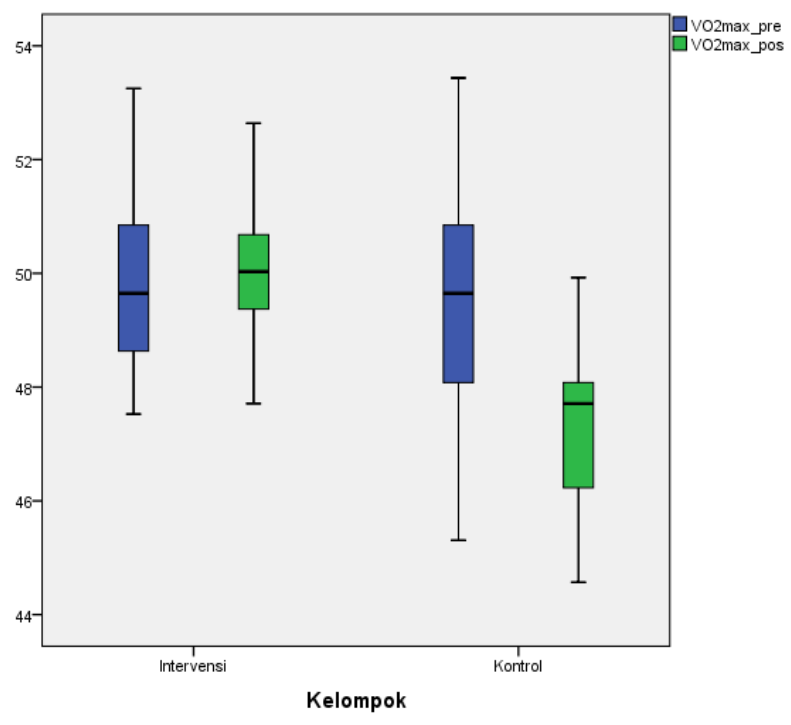

Gambar 1. Perbedaan Peningkatan Kebugaran pada Kelompok Penelitian

Gambar 1 memperlihatkan kebugaran pada kelompok intervensi lebih stabil daripada kelompok kontrol.

\section{PEMBAHASAN}

\section{Pengaruh Minuman Mix Juice terhadap Kadar Glukosa Darah Ibu Bersalin}

Persalinan bisa disamakan dengan latihan moderate continous exercise yang bisa menyebabkan stres umum fisiologis sehingga mengakibatkan gangguan homeostasis glukosa dan perubahan kebutuhan energi.

Saat persalinan ibu bersalin harus mempertahankan kadar glukosa dalam darah. Hal ini dikarenakan selama persalinan akan menggunakan sejumlah besar glukosa dan glikogen otot. Sebagai akibatnya adalah terjadi peningkatan pengurasan glukosa darah dan menghasilkan sejumlah besar asam laktat dalam darah.

Sebuah studi yang melakukan observasi pada ibu bersalin, selama fase laten persalinan konsentrasi gula darah ibu bersalin bisa mencapai $105 \mathrm{mg} / \mathrm{dl}$. Ketika pembukaan serviks $5 \mathrm{~cm}$, diberikan intervensi dengan pemberian infus oksitosin sehingga kontraksi rahim menjadi lebih kuat. Saat pembukaan $7 \mathrm{~cm}$ kadar glukosa darah mengalami penurunan menjadi $67 \mathrm{mg} / \mathrm{dl}$. Hal ini menunjukkan selama persalinan akan menggunakan cadangan glukosa dalam tubuh dikarenakan energi digunakan karena adanya kontraksi uterus.

Tabel 3 menunjukkan bahwa rerata kadar glukosa darah pada kelompok perlakuan lebih tinggi $(119,1 \mathrm{mg} / \mathrm{dl})$ dibandingkan kelompok kontrol $(104,4 \mathrm{mg} / \mathrm{dl})$. Nilai rata-rata tersebut menunjukkan keberhasilan pemberian minuman mix juice pada kelompok perlakuan dengan nilai $p<0,05$

Peningkatan kadar glukosa darah pada kelompok perlakuan adalah sebesar $34,7 \mathrm{mg} / \mathrm{dl}$, sedangkan pada kelompok kontrol juga mengalami kenaikan 16,4 mg/dl. Hal ini sejalan dengan penelitian yang dilakukan oleh Hidayat AT dkk yang memberikan minuman berkarbohidrat tinggi pada atlet dengan hasil uji paired $t$ test terdapat perbedaan yang signifikan antara kadar glukosa darah subjek setelah latihan dan setelah intervensi pada kedua kelompok baik pada kelompok kontrol maupun pada kelompok perlakuan $(p<0,05)$ (Hidayat AT, 2014). Kelompok perlakuan yang mendapatkan minuman mix juice kadar gula darah relatif lebih stabil bahkan meningkat tetapi masih dalam batas normal.

Hasil penelitian membuktikan bahwa pemberian nutrisi dengan kadar glikemiks indeks yang rendah dapat mempertahankan kadar gula darah. Terdapat perbedaan kadar glukosa darah yang diperiksa setelah persalinan pada kelompok perlakuan tinggi daripada kelompok kontrol. Hal ini sejalan dengan kandungan pada minuman mix juice yang mengandung lebih banyak glukosa dan fruktosa dari buah-buahan, madu dan kacang-kacangan.

Penelitian yang sama juga dilakukan oleh Meludu dkk dan Kalpana dkk terhadap atlet maraton yang dalam hal ini juga bisa disamakan seperti aktivitas ibu bersalin, dengan hasil terdapat peningkatan yang signifikan kadar glukosa darah serum dengan $p<0,05$ dengan pemberian minuman berkarbohidrat tinggi (Meludu et al, 2005; Kalpana et al, 2013). Hal ini dapat disimpulkan asupan karbohidrat sebelum beraktifitas tinggi dapat meningkatkan kinerja dan mengurangi penggunaan cadangan glikogen dan lemak tubuh.

Penelitian lain oleh Laurenson dkk yang membandingkan pemberian minuman karbohidrat tinggi pada atlet dengan letihan intensitas sedang, kadar glukosa post exercise signifikan lebih tinggi dibanding kelompok kontrol dengan $p<0,05$. Untuk kelompok kontrol juga mengalami kenaikan tetapi tidak setinggi kelompok perlakuan. Peningkatan insulin darah diduga berguna untuk pengisian kembali glikogen otot. Tingginya konsentrasi glukosa saat 
pemulihan ini berguna untuk mengisi kembali glikogen otot yang telah berkurang selama melakukan aktifitas fisik (Laurenson DM et al, 2015).

Subjek penelitian baik pada kedua kelompok mengalami kenaikan kadar gula darah tetapi rentang kenaikan sesudah perlakuan lebih tinggi kelompok perlakuan daripada kelompok kontrol, hal ini dikarenakan subjek penelitian pada kelompok control juga mendapatkan asupan nutrisi baik dalam bentuk padat atau cair rata-rata sebesar $46 \mathrm{kkal} / \mathrm{jam}$.

Beberapa literatur dijelaskan bahwa anjuran pemberian nutrisi selama persalinan antara 50-100 kkal/jam. Sehingga minuman ini bisa menjadi alternatif nutrisi untuk ibu bersalin. Pada penelitian ini kelompok kontrol mengkonsumsi asupan kurang dari yang dianjurkan sehingga walaupun kadar glukosa naik tetapi rerata kebugaran turun.

Minuman mix juice yang diminum oleh ibu akan bercampur dengan saliva yang mengandung enzim amilase. Enzim amilase menghidrolisis polisakarida menjadi disakarisa maltosa. Pencernaan berlanjut ketika minuman berada di lambung dan bercampur dengan asam lambung. Proses pencernaan karbohidrat kemudian berlanjut setelah kimus masuk ke usus halus. Di duodenum kimus bercampur dengan enzim amilase pankreas dan terjadi proses hidrolisis polisakarida menjadi disakarida dan polimerpolimer glukosa. Di jejunum dan ileum disakarida akan dihidrolisis oleh enzim disakaridase yang dihasilkan oleh sel epitel usus halus. Enzim-enzim tersebut akan menghidrolisis laktosa menjadi glukosa dan galaktosa, sukrosa menjadi glukosa dan fruktosa. Hasil akhir proses hidrolisis adalah monosakarida (80\% berupa glukosa) yang terlarut dalam air dan selanjutnya akan diabsorpsi oleh epitel usus halus ke sirkulasi darah melalui vena porta (Hall JE, 2015; Sherwood L, 2011).

Hasil penelitian ini membuktikan bahwa kadar glukosa darah ibu bersalin pada kelompok perlakuan lebih stabil daripada kelompok kontrol. Hal ini disebabkan komposisi bahan pembuatan mix juice mengandung lebih banyak fruktosa alami yang memiliki nilai indeks glikemik yang rendah sehingga memiliki efek fisiologis bagi kesehatan, diantaranya mampu mempertahankan konsentrasi gula darah. Selain itu kontistensi cair pada minuman menyebabkan cepat diserap tubuh dan cepat dimetabolisme menjadi energi.

\section{Pengaruh Minuman Mix Juice terhadap Kebugaran Ibu Bersalin}

Energi yang cukup akibat pasokan gula darah yang stabil akan mempertahankan tingkat kebugaran ibu selama menjalani proses persalinan. Kebugaran kardiorespiratori yang tinggi akan meningkatkan sensivitas insulin, meningkatkan transportasi glukosa dari darah ke otot, memperbaiki fungsi sistem saraf dan menurunkan denyut jantung. Kadar gula darah yang terjaga selama persalinan akan mempertahankan kebugaran ibu sehingga akan menunda kelelahan akibat proses persalinan (Miles L, 2007).

Pada proses persalinan kebugaran ibu bersalin akan mengalami penurunan karena aktivitas otot-otot untuk berkontraksi, selain itu juga energi ibu terkuras karena dorongan meneran. Oleh karena itu ibu memerlukan asupan nutrisi yang cukup supaya menguras cadangan energi di glikogen hati dan otot. Kebugaran yang kurang ditandai dengan denyut nadi yang meningkat karena proses metabolisme memasuki anaerob. Semakin bugar seseorang, maka semakin besar ukuran jantung dan semakin kuat otot jantung dalam memompakan darah ke seluruh tubuh, sehingga semakin sedikit jumlah denyut yang dibutuhkan untuk mengirimkan darah dalam jumlah yang sama ke seluruh tubuh (Hernawati, 2010)

Tabel 4 menunjukkan bahwa pada awal penelitian rerata kebugaran pre kelompok perlakuan lebih tinggi $(49,6 \mathrm{ml} / \mathrm{kg} / \mathrm{min})$ dari kelompok kontrol $(49,5 \mathrm{ml} / \mathrm{kg} / \mathrm{min})$, namun secara statistik tidak ada perbedaan yang bermakna antara kelompok perlakuan dan kontrol, hal ini menunjukkan kebugaran sebelum pemberian minuman mix juice adalah homogen. Kondisi tersebut karena karakteristik subjek penelitian hampir sama dilihat dari usia, IMT, dan durasi persalinan. Selain itu untuk riwayat obstetri subjek penelitian ini ada primigravida dan multigravida ternyata secara statistik pun tidak berbeda secara signifikan. Hal ini sesuai dengan teori yang menyatakan bahwa tidak ada pengaruh antara puncak denyut nadi selama persalinan dengan usia, body mass index, denyut nadi istirahat dan durasi persalinan. Akan tetapi nadi disini dipengaruhi oleh dorongan meneran dan adanya kontraksi $(\mathrm{R}=0,49, p<0,01)$, sehingga pemeriksaan kebugaran dengan menggunakan denyut nadi dilakukan saat tidak ada kontraksi (Soehnchen N et al, 2011).

Akhir penelitian, rerata kebugaran pada kelompok perlakuan lebih tinggi $(50 \mathrm{ml} / \mathrm{kg} / \mathrm{min})$ dibandingkan kelompok kontrol $(47,3 \mathrm{ml} / \mathrm{kg} / \mathrm{min})$. 
Nilai rata-rata tersebut menunjukkan keberhasilan pemberian minuman mix juice pada kelompok perlakuan karena

Peningkatan kebugaran pada kelompok intervensi $0,7 \%$, hal ini menggambarkan bahwa kebugaran sebelum dan setelah persalinan ibu setelah diberikan minuman mix juice relatif lebih stabil. Berbeda halnya dengan kelompok kontrol yang mengalami penurunan kebugaran sebesar 4,38\%. Hal ini membuktikan keberhasilan minuman mix juice dalam menjaga kebugaran ibu selama persalinan.

Penelitian oleh Hernawati menjelaskan bahwa pentingnya makanan dan minuman selama persalinan. Ibu bersalin yang mengkonsumsi minuman berkarbohidrat tinggi akan meningkatkan energi ibu selama persalinan. Energi ini diperlukan untuk kontraksi otot-otot uterus, dan otot dasar panggul. Kebugaran yang dihitung dari denyut nadi merupakan indikasi dari intensitas stres relatif pada cardio-respiratori system selama latihan dan merupakan pemeriksaan tidak langsung dari aktivitas. Kebugaran tubuh seseorang mempengaruhi denyut nadi, semakin bugar kondisi tubuh seseorang, semakin rendah denyut nadinya. Semakin bugar seseorang, maka semakin besar ukuran jantung dan semakin kuat otot jantung dalam memompakan darah ke seluruh tubuh, sehingga semakin sedikit jumlah denyut yang dibutuhkan untuk mengirimkan darah dalam jumlah yang sama ke seluruh tubuh (Hernawati, 2010)

Penelitian lainnya yang dilakukan oleh Anggraini $\mathrm{AD}$, dengan hasil rerata nilai $\mathrm{VO}_{2}$ max subjek yang diberi minuman berkarbohidrat sebesar $43.62 \pm 6.09$ dan termasuk dalam kategori cukup. Sebanyak $44.44 \%$ subjek memiliki kategori nilai $\mathrm{VO}_{2}$ max baik, 2 subjek $(11,11 \%)$ memiliki kategori $\mathrm{VO}_{2} \max$ baik sekali, sementara $22.22 \%$ subjek berada pada kategori $\mathrm{VO}_{2} \max$ kurang. Bukti bahwa konsumsi minuman berkarbohidrat tinggi bisa disamakan juga pada ibu bersalin karena aktifitas selama persalinan relatif sama dengan moderat continous exercise (Anggraini AD, 2013).

Penelitian lain yang memberikan minuman energi standar 45 menit sebelum latihan pada atlet wanita dibuktikan dengan kebugaran sedikit lebih tinggi daripada kelompok yang tidak diberikan minuman. Hasil $\mathrm{VO}_{2}$ max pada kelompok minuman karbohidrat tinggi adalah $34,06 \pm 6,62$, sementara itu untuk kelompok energi drink 32,89 $\pm 6,83$ (Al-Fares MN et al, 2015).

Minuman mix juice telah terbukti bisa mempertahankan kebugaran ibu bersalin, hal ini dibuktikan pada kedua kelompok walaupun kadar glukosa darah mengalami peningkatan darah tetapi kebugaran kelompok kontrol mengalami penurunan yang signifikan setelah dilakukan intervensi. Pemberian minuman mix juice dapat digunakan sebagai alternatif asupan selama persalinan karena dapat mempertahankan kadar glukosa darah dan kebugaran sehingga dapat menurunkan angka morbiditas ibu bersalin.

Beberapa kelemahan penelitian ini diantaranya; pembuatan minuman mix juice tidak dilakukan secara simultan sebelum diberikan ke semua subjek penelitian akan tetapi dilakukan setiap empat hari sekali dengan berpedoman pada hasil uji daya simpan masih aman pada hari keempat. Pemeriksaan glukosa hanya dilakukan dua kali yaitu sebelum dan setelah pemberian minuman sehingga tidak bisa diketahui irama peningkatan atau penurunan kadar glukosa selama persalinan. Penelitian ini tidak melakukan analisis kandungan mikronutrien karena keterbatasan waktu dan biaya, sehingga tidak bisa diketahui kandungan bahan secara lengkap.

\section{SIMPULAN}

Minuman mix juice telah terbukti bisa mempertahankan kebugaran ibu bersalin, hal ini dibuktikan pada kedua kelompok walaupun kadar glukosa darah mengalami peningkatan darah tetapi kebugaran kelompok kontrol mengalami penurunan yang signifikan setelah dilakukan intervensi. Pemberian minuman mix juice dapat digunakan sebagai alternatif asupan selama persalinan karena dapat mempertahankan kadar glukosa darah dan kebugaran sehingga dapat menurunkan angka morbiditas ibu bersalin.

\section{DAFTAR PUSTAKA}

ACNM. Providing Oral Nutrition to Women in Labor. (2008). Journal of Midwifery \& Women's Health, 53(3):276-83.

Adji, IS. (2010). Pengemasan dan Penyimpanan Minuman Sari Jagung. (Skripsi, Institut Pertanian Bogor).

Al-Fares MN, Alsunni AA, Majeed F, Badar A. (2015). Effect of energy drink intake before exercise on indices of physical performance in untrained females. Saudi Medical Journal, 36(5):580-6 
Anggraini AD, Murbawani EA. (2013). Pengaruh Konsumsi Minuman Madu Terhadap Kadar Glukosa Darah Atlet Sepak Bola Remaja Selama Simulasi Pertandingan. (Skripsi, Universitas Diponegoro).

Benfield RD, Newton ER, Tanner CJ, Heitkemper MM. (2014). Cortisol as a Biomarker of Stress in Term Human Labor Physiological and Methodological Issues. Biological research for nursing. 16(1):64-71.

Bogdanov S, Jurendic T, Sieber R, Gallmann P. (2008). Honey for nutrition and health: a review. Journal of the American College of Nutrition. 27(6):677-89.

DL T. (2008). Carbohydrate Loading. ACSM's Health \& Fitness Journal. 12(2):5.

Etebu E, Nwauzoma A. (2014). A review on sweet orange (Citrus sinensis L Osbeck): health, diseases and management. Am J Res Commun. 2:33e70.

Hall JE. (2015). Guyton and Hall textbook of medical physiology. Philadelpia: Elsevier Health Sciences.

Herch W, Kallel H, Boukhchina S. (2014). Physicochemical properties and antioxidant activity of Tunisian date palm (Phoenix dactylifera L.) oil as affected by different extraction methods. Food Science and Technology (Campinas), 34(3):464-70.

Hernawati. (2010). Produksi Asam Laktat Pada Exercise Aerobik Dan Anaerobik. (Skripsi, Fakultas Pendidikan MIPA Universitas Pendidikan Indonesia).

Hidayat AT, Fitranti DY. (2014). Perbedaan Kadar Glukosa Darah Atlet Setelah Latihan Antara Pemberian Sari Tebu Dan Minuman Berkarbohidrat Pabrikan. Journal of Nutrition College.8(4):880-6.

Julianti E, Nurminah M. (2006). Buku Ajar Teknologi Pengemasan. Departemen Teknologi Pertanian Fakultas Pertanian Universitas Sumatera Utara.

Kalpana K, Lal PR, Kusuma DL, Khanna GL. (2013). The effects of ingestion of sugarcane juice and commercial sports drinks on cycling performance of athletes in comparison to plain water. Asian journal of sports medicine. 4(3):181.

Khushoo TN, Rafiq N, Qayoom O. (2015). Assessment of cardiovascular fitness $\left[\mathrm{VO}_{2}\right.$ max] among medical students by Queens College step test. International Journal of Biomedical and Advance Research. 6(5):418-21.

Laurenson DM, Dubé DJ. (2015). Effects of carbohydrate and protein supplementation during resistance exercise on respiratory exchange ratio, blood glucose, and performance. Journal of Clinical \& Translational Endocrinology. 2(1):1-5.

Maharaj D. (2009). Eating and drinking in labor: Should it be allowed?. European Journal of Obstetrics \& Gynecology and Reproductive Biology.146(1):3-7.

Malin G, Bugg G, Thornton J, Taylor M, Grauwen N, Devlieger R, et al. (2016). Does oral carbohydrate supplementation improve labour outcome? A systematic review and individual patient data meta-analysis. BJOG: An International Journal of Obstetrics \& Gynaecology. 123(4):510-7.

Mariyam P, Mary V. (2015). Nutritional Analysis (Macronutrients, Potassium and Iron Content) of Four Palm Date Varieties (Phoenix dactylifera L.) and Study of Consumption Pattern among Muslim and Maharashtrian Community. $J$ Food Processing \& Beverages. 3(1):1-9.

Melo CRM, Peraçoli JC. (2007). Measuring the energy spent by parturient women in fasting and in ingesting caloric replacement (HONEY). Revista latinoamericana de enfermagem. 15(4):612-7.

Meludu S, Asomugha L, Dioka E, Osuji C, Agbasi A, Ifeanyichukwu M, et al. (2005). Exercise performance in relation to glucose drink and their effect on some biochemical parameters. Nigerian Journal of Physiological Sciences. 20(1):43-7.

Miles L. (2007). Physical activity and health. Nutrition Bulletin. 32(4):314-63.

PAGI. (2009). Tabel komposisi pangan Indonesia. Jakarta: PT Elex Media Komputindo.

Potgieter S. (2013). Sport nutrition: A review of the latest guidelines for exercise and sport nutrition from the American College of Sport Nutrition, the International Olympic Committee and the International Society for Sports Nutrition. South African journal of clinical nutrition. 26(1):6-16.

Rahmani R, Khakbazan Z, Yavari P, Granmayeh M, Yavari L. (2012). Effect of oral carbohydrate intake on labor progress: randomized controlled trial. Iranian Journal of Public Health, 41(11):59.

Sherwood L. (2011). Fundamentals of human physiology. Cengage Learning.

SNI. (1995). Standar Nasional Indonesia Minuman Sari Buah.

SNI. (2005). Minuman khusus ibu hamil dan atau ibu menyusui. 
Soehnchen N, Melzer K, de Tejada BM, JastrowMeyer N, Othenin-Girard V, Irion O, et al. (2011). Maternal heart rate changes during labour. European journal of obstetrics \& gynecology and reproductive biology. 158(2):173-8.
Wauthoz N, Balde A, Balde ES, Van Damme M, Duez P. (2007). Ethnopharmacology of Mangifera indica L. bark and pharmacological studies of its main $\mathrm{C}$ glucosylxanthone, mangiferin. International Journal of Biomedical and Pharmaceutical Sciences. 1(2):112-9. 